\title{
DEVELOPMENT OF A FUNCTIONAL FOOD ADDITIVE FROM CINNAMON BARK RESIDUE (REMAIN AFTER OIL DISTILLATION)
}

By

MEEMANAGE SISIRA NANDANA PERERA

Thesis submitted to the University of Sri Jayewardenepura as the partial fulfillment requirement for the award of the degree of Masters of Food Science and Technology on 2008 


\section{DECLARATION}

"The work of this thesis was carried out by me at the Herbal Technology Section and Pilot Plant of Industrial Technology Institute, under the supervision of Dr G.A.S. Premakumara, Mr. K.R. Dayananda and Dr U.M. Senanayake and this has not been submitted in whole or in part to any University or Institution for another Degree/ Diploma"

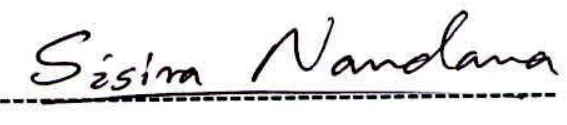

Meemanage Sisira Nandana Perera 
"We certify that the above statement made by the candidate is true and that thesis is suitable for submission to the University for the purpose of evaluation."

1. Dr. G A S. Premakumara

Head, Herbal Technology Section

Industrial Technology Institute, Colombo 07

2. Mr. K.R. Dayananda

Senior Research Officer

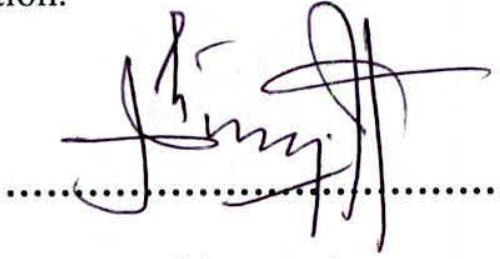

(signature)

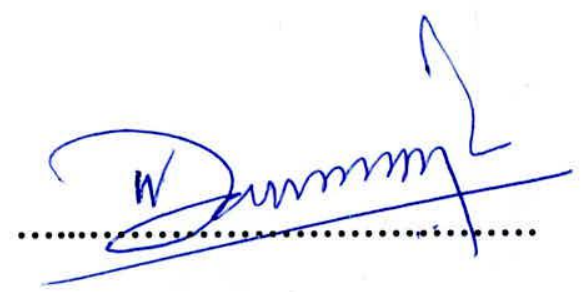

(signature)

Herbal Technology Section

Industrial Technology Institute, Colombo 07.

3. Dr U.M. Senanayake

Visiting Lecturer

(signature)

Department of Food Science and Technology

University of Sri Jayawardenepura

Gangodawila, Nugegoda.

4. Dr K.K.D.S Ranaweera

Head, Department of Food Science and Technology

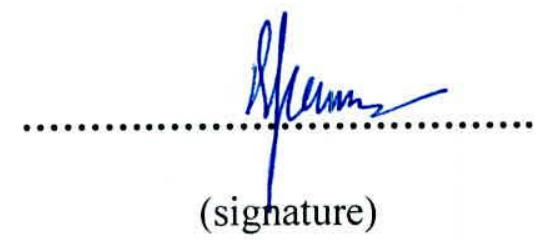

University of Sri Jayawardenepura

Gangodawila, Nugegoda. 


\section{TABLE OF CONTENTS}

Table of contents

Pages

i

List of Tables $\quad$ iv

List of Figures

Acknowledgement vi

Abbreviations $\quad$ viii

$\begin{array}{ll}\text { Abstract } & \text { ix }\end{array}$

CHAPTER 1 - INTRODUCTION 1

CHAPTER 2 - LITERATURE RIVIEVE

2.1 Taxonomy and the distribution of Cinnamomum zeylanicum, Blume $\quad 7$

2.2 Traditional uses of C. zeylanicum 11

$\begin{array}{ll}2.3 \text { Health benefits and medicinal uses of cinnamon } & 13\end{array}$

$\begin{array}{ll}\text { 2.4 Nutritional facts of cinnamon } & 17\end{array}$

$\begin{array}{ll}\text { 2.4.1 Nutritional profile of cinnamon } & 17\end{array}$

2.5 Safety issues of cinnamon 22

2.6 Description of cinnamon and history 23

$\begin{array}{ll}\text { 2.6.1 Origin of cinnamon } & 23\end{array}$

2.6.2 Scientific calcification of cinnamon 26

$\begin{array}{ll}\text { 2.6.3 Cassia, Cinnamonum aromaticum } & 27\end{array}$

$\begin{array}{ll}\text { 2.6.4 Cinnamon and Cassia } & 29\end{array}$

2.6.5 History of cinnamon 31

$\begin{array}{ll}\text { 2.6.6 Cinnamon as a common flavor } & 34\end{array}$ 
$\begin{array}{ll}\text { 2.6.8 Quality parameters of cinnamon } & 37\end{array}$

$\begin{array}{ll}\text { 2.6.9 Grading of cinnamon bark } & 37\end{array}$

2.6.10 Essential oil of cinnamon $\quad 40$

2.7 Distillation of cinnamon bark oil $\quad 42$

2.7.1 Commercial uses of cinnamon oil 43

2.8 Chemical composition and scientific investigations of cinnamon oils $\quad 44$

2.8.1 Sri Lanka cinnamon oil constituents in bark, leaf, root and fruit $\quad 44$

2.8.2 Major constituents, Chemical Structure and Solubility of the oils $\quad 46$

2.8.3 Major Constituent of Cinnamon Bark oil in different areas $\quad 47$

2.8.4 Comparison of Sri Lankan cinnamon with cassia 48

3.0 CHAPTER 3-EXPERIMENTAL METHODOLOGY 48

$\begin{array}{ll}3.1 \text { Materials } & 49\end{array}$

3.1.1 Equipments and chemicals used for preparation of $\begin{array}{ll}\text { cinnamon concentrate } & 49\end{array}$

$\begin{array}{ll}3.2 \text { Methods } & 49\end{array}$

3.2.1 Laboratory trials for the cinnamon $\quad 49$

3.2.2 Pilot Plant extraction of the cinnamon residue (after oil distillation) $\quad 49$

$\begin{array}{ll}\text { 3.2.3 Spray drying of concentrated extracts } & 50\end{array}$

3.2.4 Product formulation as a food additive $\quad 50$

3.2.5Flow chart for extraction of cinnamon waste $\quad 51$

3:3 Products and materials testing $\quad 52$ 
3.3.2 Determination of $\mathrm{pH}$ values

3.3.3 Determination of total dissolved solid (TDS)

3.3.4 Determination of total ash content

3.3.5 Determination of crude fiber content

3.3.6 Determination of total dietary fiber content

3.3.7 Determination of total polyphenol content

3.3.8 Microbiological Analysis

3.3.9 Sensory Evaluation

CHAPTER 4 - RESULTS

4.1 Raw material testing

4.2 Results of the tested materials

4.3 Product Testing

4.4 Microbiological Quality of the Products 66

4.5 Recommended dosage of developped products for type 2 diabetes 66

4.6 Sensory quality of the bread ( formulated tablet added as food additive) 68

CHAPTER 5 - CONCLUSIONS 78

REFERENCES 


\section{LIST OF TABLES}

Pages

Table i Distribution of cinnamon lands in each district in 2002.

Table ii Provision of nutrients of 2 tea spoons of cinnamon powder on daily basis 17

Table iii In-depth nutrient analysis of ground cinnamon powder $\quad 18$

Table iv World's Healthiest Foods Rating system for cinnamon 20

Table v Nutrition Facts of ground cinnamon powder 21

Table vi General quality parameters of cinnamon bark $\quad 37$

Table vii Grading of cinnamon bark for the export market 39

Table viii Composition of cinnamon oils $\quad 45$

Table ix Major component of Sri Lankan Cinnamon Bark oil 46

Table x Major Constituent of Cinnamon Bark oil in different areas 47

Table xi Comparison of major constituents of Sri Lankan $\begin{array}{ll}\text { cinnamon oil with cassia oil } & 61\end{array}$

Table xii Test result of the products and cinnamon powder $\quad 64$

Table xiii Test result of the microbiological analysis $\quad 66$ 


\section{LIST OF FIGURES}

Pages

Figure i Cinnamomum zeylanicum leaves with flowers

Figure ii Sri Lankan Cinnamon plants

Figure iii. Dried cassia bark

Figure iv Quills of the true cinnamon bark

Figure v processing steps of the cinnamon quills 36

Figure vi Traditional cinnamon oil distillation plant 40

Figure vii Modern cinnamon bark oil still 41

Figure viii Chemical Structure of the cinnamon oils 46

Figure ix Process flow diagram 51

Figure $\mathrm{x}$ Developed process flow chart for instant cinnamon waste powder 60

Figure xi Developed spray dried cinnamon waste powder as food additive 61

Figure Xii Formulated tablets as food additive 62

Figure Xiii Formulated capsules from spray dried powder as functional food 63 


\section{ACKNOWLEDGEMENT}

Fist and foremost I wish to thank with deepest gratitude to my supervisors Dr.G A S. Premakumara, Head, Mr. K.R. Dayananda, Senior Research Officer Herbal Technology Section, Industrial Technology Institute,Herbal Technology Section, Industrial Technology Institute, and Dr. U. M. Senanayake, Visiting Lecturer Department of Food Science and Technology University of Sri Jayewardenepura for there valuable guidance, encouragement and suggestions given through out my research project.

I extend my special thanks to Dr. K.K.D.S. Ranaweera, Head of Department of Food Science and Technology, Course Coordinator of the M.Sc. in Food Science and Technology program, University of Sri Jayewardenepura and to all the academic and non academic staff of the department.

I would like to thank Miss. N.T. Amarasinghe, Project Leader, Coir Project, Former Head, Process and Plant Engineering Division ITI for providing me the opportunity to carry out pilot plant trials and valuable guidance and help for the research project.

I am pleased to acknowledge the assistance of Mr. Bandulasoma, Head, Chemical and Microbiology Laboratory, Mr. J.A.G. Jayasinghe, Senior Research Officer, ITI, Chemical and Microbiology Laboratory, ITI and Mr. Sarath Kumara, Senior Technical Officer, Mrs. Sirima Ahangama, Senior Technical Officer, Mrs. Suchitha Perera, Technical Assistant, and Miss. Kanchana Abesekara, Research Assistant for Analysis of final product. 
I sincerely thank my friends Mr.Colin Peris, Mrs.L.D.A.M. Arawwawala, Mrs. P.I P K Fernando, Mrs. V.S. Bandara, Mr. Asitha Siriwardena, Miss. K. Abeysekara and the staff of Herbal Technology Section for their constant support and encouragement given during this.

Finally I wish to express my deepest gratitude to my loving wife Sepali and my children Sahan, Dasun and Lakmanthi for their encouragement and moral support during this study. 


\section{ABBREVIATIONS}

\begin{tabular}{|c|c|}
\hline $\mathrm{w} / \mathrm{w}$ & Weight basis \\
\hline USDA & United State Department of Agriculture \\
\hline $\mathrm{BC}$ & Before Christ \\
\hline IDDM & Insulin-dependent diabetes mellitus \\
\hline NIDDM & Non-insulin-dependent diabetes mellitus \\
\hline LDL & Low density lipoprotein \\
\hline HDL & High density lipoprotein \\
\hline $\mathrm{CE}$ & Common Era \\
\hline $\mathrm{BCE}$ & Before the Common "Christian", or "Current Era" \\
\hline $\mathrm{AD}$ & Ano Domini \\
\hline GRAS & Generally recognized as safe \\
\hline FDA & Food and drug authority \\
\hline USA & United State of America \\
\hline MHCP. & Methyl hydroxyl chalcone polymer \\
\hline MPN & Most probable number \\
\hline SLS & Sri Lanka Standard \\
\hline DF & Dietary fiber \\
\hline IP & Indigestible protein \\
\hline
\end{tabular}




\title{
DEVELOPMENT OF A FUNCTIONAL FOOD ADDITIVE FROM CINNAMON
}

\section{BARK RESIDUE (REMAIN AFTER OIL DISTILLATION)}

\section{BY Meemanage Sisira Nandana Perera}

\author{
ABSTRACT
}

Cinnamomum zeylanicum (Family: Lauraceae) is one of the world's most popular spices. It is locally known as "Kurundu" and widely distributed in Galle and Matara districts in Sri Lanka. C. zeylanicum is known to possess a broad spectrum of pharmacological and medicinal properties. Water soluble polyphenol polymers and dietary fiber found in cinnamon exhibit cholesterol and triglyceride lowering effect, insulin stimulating activity, antioxidant activity and many other health benefits.

In Sri Lanka large quantities of cinnamon waste is accumulated in cinnamon oil distillation plants. Furthermore, bioactive polyphenolic compounds are remained in the cinnamon waste without any disturbances during the oil distillation process. At present, there is no process developed to give a value addition to the cinnamon waste in Sri Lanka. Therefore, the main objective of the present study was to develop a process to get an instant cinnamon powder from cinnamon bark waste that remains after oil distillation. In addition, development of functional food additives from cinnamon waste and determination of nutritional parameters such as polyphenol content, dietary fiber content and mineral content were also some of the other objectives.

In the present study, water soluble components were extracted to boiling water and concentrated under vacuum at $70-80{ }^{\circ} \mathrm{C}$ and the cinnamon concentrate was obtained. The total solid content in the cinnamon concentrate was found to be $12 \%$ and this factor was 
used as the standard parameter for the cinnamon concentrate. Further, cinnamon concentrate was subjected to spray drying and the instant cinnamon powder was obtained. In order to develop a nutraceutical, gelatin capsules were filled with instant cinnamon powder (approx. $300 \mathrm{mg}$ each) and standardized by determining the polyphenol content. Each cinnamon capsule contained $14.3 \%$ total polyphenols. Cinnamon tablet was formulated using cinnamon concentrate (containing $12 \%$ total soluble solids) obtained from oil distilled cinnamon waste and ground cinnamon bark powder in a ratio of $3: 1(\mathrm{w} / \mathrm{w})$. This tablet was rich in polyphenols $(5.9 \% \mathrm{w} / \mathrm{w})$, dietary fiber $(72.2 \% \mathrm{w} / \mathrm{w})$ and minerals (Ca: $3239 \mathrm{mg}, \mathrm{Mn}: 11.3 \mathrm{mg}$, and Fe: $12.8 \mathrm{mg}$ in $\mathrm{Cu} 2.9 \mathrm{mg}$ and $\mathrm{Zn} 1.3 \mathrm{mg}$ in $100 \mathrm{~g}$ of tablet). Cinnamon enriched bread was formulated with addition of $2 \%-5 \%$ blended powder and sensory quality was evaluated. The panel accepted the bread that incorporated $5 \%$ cinnamon powder with the highest rating.

This is the first report of utilization of cinnamon waste to develop instant cinnamon powder in Sri Lanka. In addition, cinnamon capsules, tablets and value added products obtained from the same waste were also formulated which could be consumed as a functional food additive to improve general health. 


\section{CHAPTER 1}

\section{INTRODUCTION}

Ceylon Cinnamon (Cinnamomum zeylanicum) is a genus indigenous to Sri Lanka. Cinnamon has been in use since at least 2700 B.C. and it is one of the world's most popular spices. In Sri Lanka, Dutch Settlers started commercial cultivation of Cinnamon in 1767 but market expanded during British period and large shipments moved to serve the European market. The traditionally known cinnamon was the peeled cinnamon bark (Wijesekera, 1978). After harvesting, the leaves and the tender stems are removed and the shoots are taken for 'peeling'. Peeling is a very specialized operation demanding the use of skilled labour. First, the soft outer bark is scraped off with a fine rounded rasp. Then two longitudinal cuts are made in the bark to enable a fine string of bark to be removed. The rest of the bark, which is in tubular form is gradually loosened and peeled off with a blunt knife. The peeled bark is then carefully rolled into another to form a packing of concentric tubes. Small pieces of the bark left after peeling are stuffed inside these tubes, which reach a length of about $1 \mathrm{~m}$. They are allowed to dry initially 2 hours in the sun and then on coir rope racks in the shade. Periodically they are hand compressed to help acquire the tubular form, which is known in commerce as 'quills'. The 'quills' facilitate storage and transportation. These quills are exposed to smoke of Sulphur for about $24 \mathrm{hr}$ for sterilization and prevent the growth of fungi and moulds during storage. These quills are graded according to the quill diameters, number of quills per $\mathrm{kg}$, thickness and the colour. The finest and smoothest quality quills are said to be the best and name as "Alba". About 
$90 \%$ of cinnamon produce is exported as quills which count to $\sim 15000 \mathrm{t}$ annually (Wijesekera, 1978).

Broken pieces of quills of various grades are called quillings and marketed as "medium quality" cinnamon 'Feather like' short shavings and small pieces of bark left over in the process of making quills are called featherings and these are also marketed as "medium quality" cinnamon. Both quillings and featherings have the distinct aroma and taste similar to quills even though they fall into a lower grade and sold at lesser price. Both types use as the raw material for cinnamon bark oil industry (Wijesekera, 1978).

Cinnamon bark taken from cinnamon tree (Cinnamomum zeylanicum) is used as a spice, which is generally formed in to quills or as ground powder. There are more than one hundred varieties of cinnamon. Ceylon cinnamon (Cinnamomum zeylanicum) and Chinese cinnamon (Cinnamomum aromaticum) are the leading varieties consumed as spice. Ceylon cinnamon is also referred to as "true cinnamon", while the Chinese variety is known as "cassia" or Chinese cinnamon while both are relatively similar in characteristics and both has a fragrant, sweet and warm taste. However, flavor of the Ceylon variety is more refined and subtle. Cinnamon has a long history both as a spice and as a medicine. Ceylon cinnamon is rare in EU market than the cassia, the less expensive variety, which is marketed in large quantity. It is reported that cassia contains significant amounts of coumarin $(15 \%)$ as toxic compound where as Ceylon cinnamon contains trace amounts. Ceylon cinnamon is produced in Sri Lanka, India, Madagascar, Seychelles, Brazil and the Caribbean while cassia is mainly produced in China, Vietnam, Indonesia and several other Asian countries. 